\title{
Ewa Hącia
}

Maritime University of Szczecin

e-mail: e.hacia@am.szczecin.pl

ORCID: 0000-0003-4865-7901

\author{
Aleksandra Lapko \\ Maritime University of Szczecin \\ e-mail: a.lapko@am.szczecin.pl \\ ORCID: 0000-0003-0235-6329
}

\section{STAFF TRAINING FOR THE PURPOSES OF MARINA MANAGEMENT ${ }^{*}$}

\section{KSZTALCENIE KADR NA POTRZEBY PORTÓW JACHTOWYCH}

DOI: $10.15611 / \mathrm{pn} .2019 .10 .13$

JEL Classification: M12, Z30, Z32

\begin{abstract}
Summary: The main purpose of the article is to present issues of staff training for the purposes of marina management. Particular attention was paid to training as a way to improve and develop marina employees. The problem was presented using the example of specialized training for marina employees and operators. It was prepared according to a training process - a procedure based on selected research techniques such as CAWI, nominal and interactive groups. Analysis of the entire training process presented in the article allowed for the formulation of conclusions. It was shown that there is a need to organize training courses for marina staff covering various thematic blocks in the training program consistent with the current situation and trends observed in nautical tourism.
\end{abstract}

Keywords: marina management, staff training, services, nautical tourism, water tourism.

Streszczenie: Głównym celem artykułu jest przedstawienie zagadnienia kształcenia kadr na potrzeby portów jachtowych. Szczególną uwagę zwrócono na szkolenia jako sposób na doskonalenie i rozwój pracowników portów jachtowych. Problem zaprezentowano na przykładzie specjalistycznego kursu dla pracowników i operatorów marin. Został on przygotowany według procesu szkolenia - procedury opartej na wybranych technikach badawczych, takich jak CAWI, grupa nominalna i interaktywna. Analiza całego procesu szkolenia przedstawionego w artykule pozwoliła na sformułowanie wniosków. Wykazano, że

* The results of the research were created within the framework of the research work No. 1/S/ PUBL/2018 financed by subsidies from the Ministry of Science and Higher Education for the financing of statutory activities. 
występuje zapotrzebowanie na kursy doszkalające pracowników portów jachtowych, uwzględniające w programie kształcenia różne bloki tematyczne. Jednakże muszą one być zgodne z aktualną sytuacją i trendami obserwowanymi w turystyce żeglarskiej.

Słowa kluczowe: zarządzanie mariną, kształcenie kadr, usługi, turystyka żeglarska, turystyka wodna.

\section{Introduction}

According to the definition, human resources management (HRM) is the process of managing human talent to achieve an organization's objective, if the organization competes through people to achieve success, this success is measured by the ability to manage human capital [Snell, Morris, Bohlander 2015]. Another definition simply describes human resources as a strategic, homogeneous and coherent method of managing the most valuable capital of any organization - people [Armstrong 2001]. The objectives of HRM are related to the basic activities and goals of the organization, i.e. creating values and conditions that are crucial for its survival and development [Romanowska 2011]. Within the area of human resources development, various forms of improvement are planned, including training. However, most often the training itself relates to teaching employees how to perform activities in a given workplace. In contrast, improvement treated as a broader concept applies to both managers and other employees [Hubner, Baum 2018]. Comprehensive personnel improvement programs, including specialized training/courses, are adapted to the specificities of the industry.

The aim of this article is to present the issue of staff training for the purposes of marina management. Particular attention was paid to training in its broader sense, i.e. as a way to improve and develop marina employees. The issue was presented using the example of a specialized course for marina employees and operators, which was organized as part of the SCB project - South Coast Baltic (Establishing durable cross-border boating destination management on the basis of the MARRIAGE cooperation network). It was prepared according to the training process - a procedure based on selected research techniques such as CAWI, nominal and interactive groups.

\section{A marina and its specificity in the aspect of training needs}

A marina is a set of port basins, hydrotechnical port buildings, land constructions and technical devices ensuring safe mooring and servicing of yachts and other floating units and vessels [Mazurkiewicz 2010]. These are typical facilities in which services for vessels, land transport means and people are provided. These services are characterized by great diversity, and their scope and quality depend on many factors. One of them is the employed staff-their knowledge, competences and communication skills. It is the staff of a given facility that plays a key role in shaping customer 
satisfaction [Pender, Sharpley (eds.) 2008] and in the sustainable development of nautical tourism [Sevinc, Güzel 2018].

There are no generally accepted standards regarding the number, structure of employment and employee positions in these facilities. The adopted model depends on many factors such as the size of a given marina, location, profile and specificity of activity, customers served (residents, tourists), the type of vessels served, the number and scope of services rendered, etc.

The form of port ownership (public, private) is also of great importance [Forkiewicz 2015]. A different employment policy applies to a sailing club, and a different one to a city marina or a typical private port focused on generating profits. However, in each case employees who have direct contact with customers play a key role in shaping customer feedback. They are usually employed as harbor masters.

In Poland, the scope of staff training for the purposes of tourist enterprise management is very wide and implemented both at the level of high schools and universities [Tokarz-Kocik 2016; Szymańska 2009]. However, it is difficult to treat marina as a typical tourist enterprise, because handling tourists usually constitutes only one of its many functions. The employed staff must not only possess skills related to tourist services, but also very specific technical skills related to the yachting operation. Marina activities are characterized by exceptional (even for the tourism industry) seasonality. This usually results in limited human resources - especially when it comes to permanent employees. Therefore, these people must have the ability to combine many functions. Typical training is not enough for marina employees. They must have the appropriate practical skills typically associated with sailing. Although, along with the growing popularity of nautical tourism, the demand for marina employees is increasing, there is still a lack of a training programme dedicated to this group of employees.

This has been noted by members of the South Coast Baltic project team. Project is financed under the Interreg South Baltic Programme 2014-2020, which began in October 2016 and was to be completed on September 30, 2019. The total budget amounted to more than 2.5 million euros. The project involved fourteen project partners, from Denmark (1), Germany (4), Poland (7), and Lithuania (2) as well as ten associated partners covering all five countries in the programme. The partnership consists of local authorities, universities, tourist and sport organisations, and marina management. The core partners are supported by eight associated partners such as tourism organisations, NGOs operating in the tourism sector, harbours, marinas, and local authorities. The overall idea of the project was to make the cross-border boating region durably attractive through establishing a comprehensive cross-border destination management which would combine joint marketing, the aim of which is e.g. brand development, with improvements of boating services and infrastructure.

One of the project partners is the Maritime University of Szczecin, which is responsible for educational and training activities. It was recognized that the qualified 
staff of marinas are the basis for the development of nautical tourism in the region. Educational and training activities undertaken as part of the project include both future and current marina staff. The future employees are educated by establishing a 1.5-year long specialization at the Maritime University of Szczecin (Marina Management and Water Tourism Logistics). The training of people currently employed in marinas of the region was carried out through specialized training dedicated to marina employees and operators. Both of these activities are unique on a European scale.

However, just like in tourist enterprises, the main purpose of marina management should be to provide a good experience to tourists [Sumathi 2018].

\section{Training process}

The training for marina employees and operators organized as part of the SCB project was prepared and carried out in accordance with the algorithm shown in Figure 1. This is called planned training - targeted intervention aimed at acquiring the knowledge necessary to achieve better results [Kenney, Reid 1994].

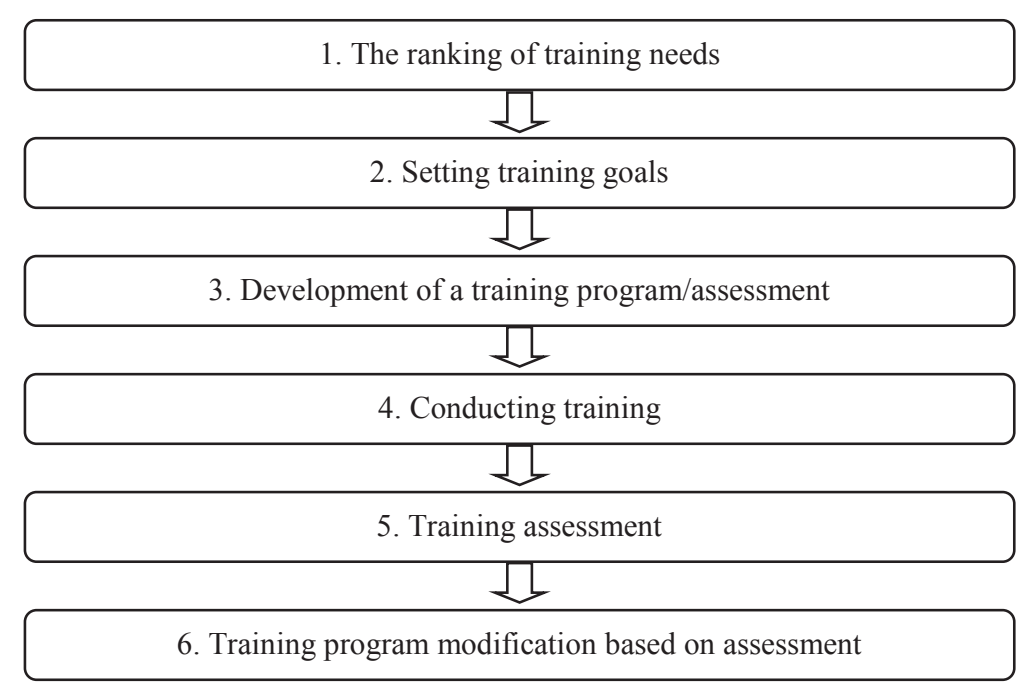

Fig. 1. Training process

Source: study based on [Armstrong 2002; Kenney, Reid 1994; Kunasz 2006a; Kunasz 2006b; Łaguna 2014; Pocztowski 2007; Rae 1999].

The ranking of training needs, i.e. the first stage of the process, was carried out in two phases. First, respondents were asked about expectations regarding the training. The goal of this phase was to gather initial topic suggestions. This was 
carried out at a meeting organized by the SCB project partners in October 2017. The meeting was attended by representatives of Polish marinas and those representing institutions supporting their management. In this way a group of people with the features of a nominal and interactive group was assembled [Szczepańska-Woszczyna 2009]. These were also potential participants in future training. The discussion was open and its purpose was to obtain ideas for issues that should be discussed during the training. The discussion moderator informed those present that the ideas developed would be subject to further evaluation.

In the second phase of the ranking of training needs, the CAWI (Computer Assisted Web Interview) research technique was used, i.e. an online survey [Przewłocka 2009]. The survey was addressed mainly to the SCB project partners, affiliates and entities associated with nautical tourism in the southern Baltic region. The survey contained a list of thematic areas (Table 1), which were suggestions obtained as part of the first phase of the training needs survey. The respondents were asked to rank (on a scale of 1 to 5) the suitability of the proposed topics for marina employees, where 1 meant that the subject area was of little use, and 5 meant that it was very useful. The respondents also had the opportunity to submit additional topics that could be of interest to the participants of training. In addition, there was information that the topics with the highest number of votes will be included in the training program. The purpose of this phase was to obtain an evaluation of individual thematic blocks in terms of the usefulness of individual content.

Table 1. Topics proposed for marina employees and operators

\begin{tabular}{|c|l|}
\hline Symbol & \multicolumn{1}{|c|}{ Topic } \\
\hline T1 & $\begin{array}{l}\text { Marketing in marinas: what to do alone as a marina? What to do together with others as } \\
\text { a destination? The importance of social media for the development of nautical tourism } \\
\text { (how it works, how it can be used, who are the users). }\end{array}$ \\
\hline T2 & Trends in nautical tourism \\
\hline T3 & $\begin{array}{l}\text { Yacht ports for everyone - how can they be adapted to the needs of elderly sailors, } \\
\text { disabled and families with children? }\end{array}$ \\
\hline T4 & $\begin{array}{l}\text { Information and its importance (how to organize a tourist information point in the port, } \\
\text { how to train staff, but also information flow in port and between SCB ports - how it } \\
\text { should look like and why). }\end{array}$ \\
\hline T5 & $\begin{array}{l}\text { Review of selected sailing regulations in Poland, Germany, Denmark and Lithuania } \\
\text { (when one can board a yacht, when to call for services, what data can be requested from } \\
\text { sailors, etc.) }\end{array}$ \\
\hline T6 & $\begin{array}{l}\text { How to welcome a tourist ('Savoir faire' of sailing, basic phrases, how to safely moor } \\
\text { a yacht) }\end{array}$ \\
\hline T7 & How to deal with a difficult client? \\
\hline T8 & Construction of a yacht \\
\hline
\end{tabular}

Source: own study. 
The online survey resulted in 18 responses. Most of them were made by entities representing marinas from Poland, Germany and Lithuania. In addition, information was also obtained from companies providing services to sailors and ports, as well as representatives of organizations cooperating closely with them (including consultancy companies, and tourist organizations) from the above-mentioned countries. It is worth noting that the respondents also included representatives of the Local Tourist Organization of the West Pomeranian Sailing Route and the Association of Sea Cities and Municipalities (ZMiGM) based in Gdańsk. The first of these organizations represents a network of about 40 ports and marinas in the Zachodniopomorskie [West Pomerania] region. These ports are located along the Odra, the Szczecin Lagoon and the Baltic Sea [www.marinas.pl]. ZMiGM is an association of about 30 coastal self-governments from the Polish coast [www.zmigm.org.pl], therefore it could be considered that the responses obtained may reflect the training needs for marinas. However, in analyzing the results of the survey, it was assumed that each of the responses carries the same weight so as not to underestimate the opinions of German and Lithuanian respondents.

The analysis of the survey concerned both the total assessment assigned to the proposed thematic areas by the respondents and the distribution of scores within each of them individually and in comparison with the others.

The assessed thematic areas were ordered in accordance with the obtained total points assessment. The maximum total number of points obtained, i.e. assuming that all respondents assess a given topic as the most needed (out of 5) was 90 . The ranking created in accordance with this criterion is shown in Figure 2. The highest rated topic related to the adaptation of marinas for elderly sailors, the disabled and families with

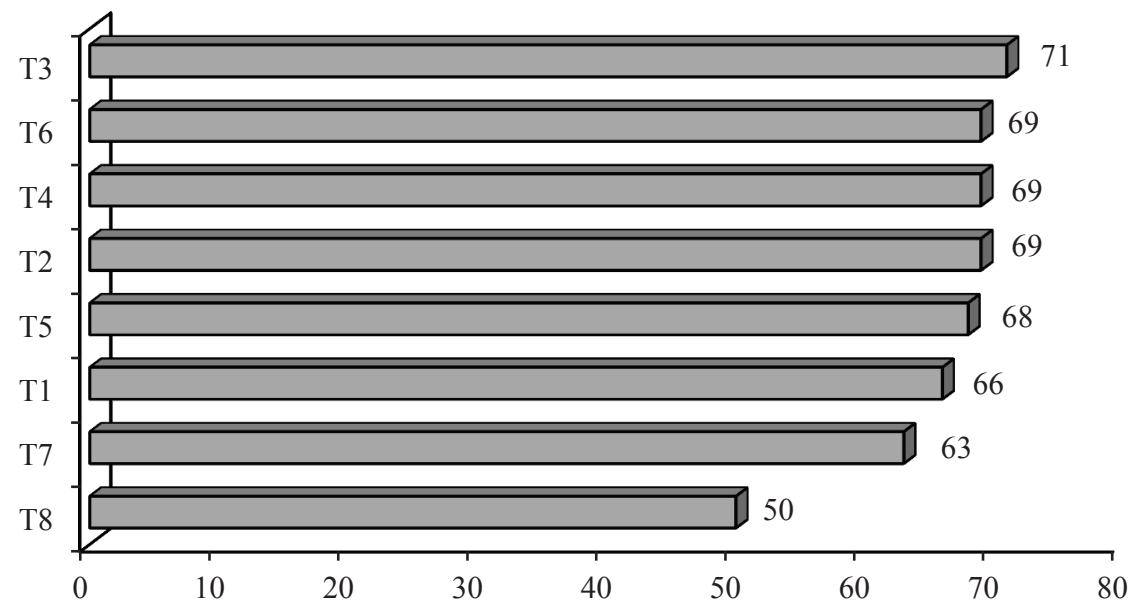

Fig. 2. Ranking of thematic areas according to the sum of ranks

Source: own study. 
children (T3). As results from earlier studies [Łapko 2018; Wassertourismus in Deutschland... 2012] this is a problem that is more and more often appearing in marinas. Its solution obviously requires investment activities in the marina infrastructure, but education in this field is equally important.

Figure 3 presents a histogram of the distribution of assessments obtained for the thematic area ranked as most important (T3). It is a distribution with a clear left-hand asymmetry. The dominant feature of this case is 5 , which means that the majority decided that this is the most necessary issue for marina staff. Still only in relation to the topic, which came in second place in the ranking (T6), the most frequently appearing rating is the highest one. In other cases, the lower grades are dominant -4 , and in two cases (T1 and T8) even 3.

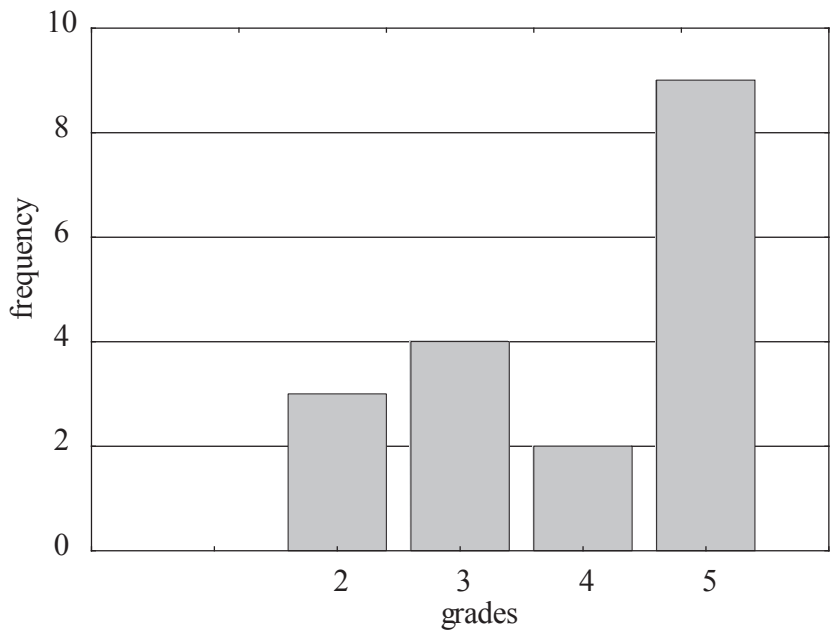

Fig. 3. Histogram of the distribution of grades for the thematic block T3

Source: own study.

In order to compare the distribution of assessments for individual thematic blocks in terms of central tendency, dispersion and asymmetry, boxplots were prepared - see Figure 4. In this way the median, lower and upper quartiles, minimum and maximum of values were illustrated [Aczel, Sounderpandian 2018]. The average values of assessments have been added (marked as plus on the charts). As can be seen, the distributions for topics T2, T7 and T8 differ from the others. The first two are very similar, except that T7 was rated lower (Figure 2). In both cases it is left-hand asymmetry, but the values of both the median and upper quartile coincide and are graded 4 . This is also the most common value, except that in the case of T2 there are more - hence the higher average and total rating.

Another noteworthy issue is the T8 topic (Construction of a yacht), which obtained the lowest overall rank (Figure 2). It is also the only area that did not receive any highest rank, while the dominant value, as already mentioned, was 3 . In this area $25 \%$ of respondents rated this topic as at the most 2 , while $50 \%$ rated at most as 3 . 
Fig. 4. Boxplots of the evaluation for the analyzed thematic blocks (T1-T8)

Source: own study.

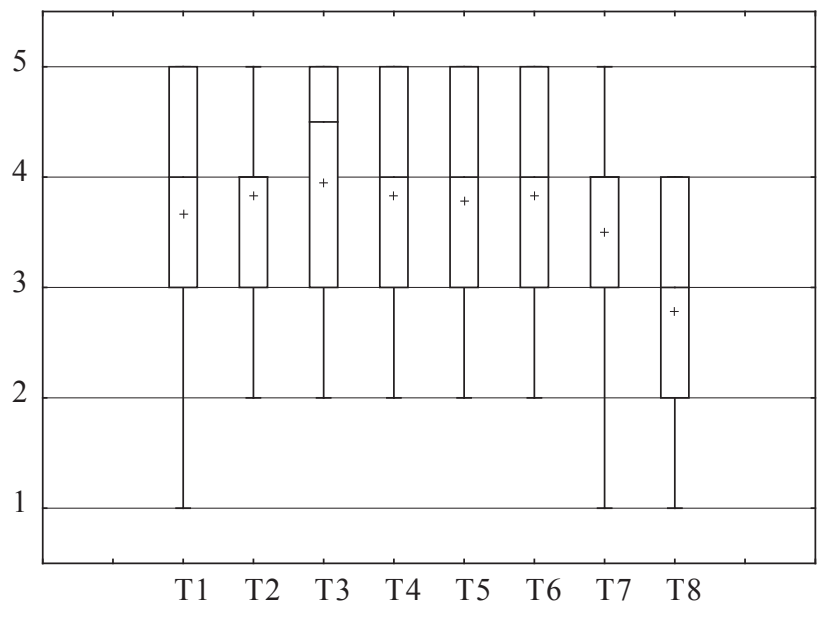

Due to the results obtained this issue was considered the least interesting for future course participants; perhaps it was decided that marina employees do not need to have broader knowledge in this area, or that other issues at the time of conducting the survey turned out to be more necessary or interesting (which was confirmed in the survey results).

The respondents only slightly referred to the request to provide their own suggestions for issues to be implemented during the training. One of them concerned specialized services that are worth developing in marinas. However, this could refer to most of the topics proposed in the survey. A similar situation regards the second proposal, which concerned marina management (in an organizational sense).

Almost in parallel with the study of training needs, the training goals were formulated. It was assumed that the training would be prepared for an international group of about 20 participants (this also resulted from conversations with interested parties) and would be conducted in English. It was addressed to operators and harbour masters, i.e. people who manage ports as well as deal with operational work and have direct contact with clients.

After thoroughly analyzing the results of the training needs, a training program and a method of its evaluation were developed (stage three). The course lasted three days and was conducted in November 2018 (stage four). Participants were persons employed in marinas located in the provinces of West Pomerania, Pomerania, as well as in Latvia. This was due to the fact that ultimately these people were willing to take part in the training and took part in the recruitment procedure. For many participants, an obstacle proved to be the language in which the training was conducted. In particular German marina employees reported that they do not speak English. This is surprising since it is the basic language in the tourism industry, and its knowledge makes handling foreign tourists much easier. 
On the first day of training the participants took part in a professional first aid course, after which they received European Resuscitation Center certificates. The course was held at RescueLab in Szczecin, and its program was adapted to the needs of marina employees. The remaining two days took the form of workshops covering the thematic issues highlighted in the training needs survey (T1-T7).

Part of the training was dedicated to the elderly and disabled (the highest rated topic) and classes in this area were conducted using a special suit - an old-age simulator. There was also a presentation of 'good practices' used in marinas, which contribute to increasing the comfort of senior sailors.

The instructors included those experienced in managing marinas from Denmark, Croatia and Germany, as well as academic teachers from the Pomeranian Medical University, the Maritime University of Szczecin and the University of Szczecin. These people were selected for the thematic issues implemented during the training.

On the last day of the course an evaluation survey was carried out, i.e. the fifth stage of the whole process. In the prepared survey, participants ranked the practical information obtained before the training, individual thematic blocks, the whole training, the need to organize subsequent editions and had the opportunity to propose future topics. A scale of 1 (very poor) to 5 (excellent) was used. As for the ranking of information obtained before the training, it was rated very high, which is valuable feedback for organizational reasons. Among the implemented thematic blocks, the highest rank was given to the service for the elderly and disabled, especially the presentation of 'good practices' used in marinas in this area. Marina marketing and the entire first aid course on the first day also received high rating. The lowest rated issues related to trends in nautical tourism - some based on the example of Croatia, which may be due to the fact that employees of the Baltic marinas do not identify with the Adriatic experience. The overall impression of the training was rated quite highly. All the participants gave it at least a score of 4 . The answer to the question about the need to organize similar training in the future was positive in all the surveys. Proposals of future topics included IT infrastructure, marketing and financial issues related marina management.

Analysis of the entire training process of marina operators and employees allows for program modifications in future editions (sixth stage). The low assessment of a given thematic block is influenced by several factors, such as the lecturer, listener, method of transferring content, available teaching aids, etc. Improving training requires the use of the whole process (Figure 1) in a cyclical manner. The first stage turned out to be labour-intensive, although extremely important. Undoubtedly, in subsequent editions of this type of training it may turn out that it is necessary to repeat the assessment of training needs, due to the constantly developing nautical tourism in the Baltic Sea region [Butowski 2018]. 


\section{Conclusions}

The analysis presented in the article regarding the organization of the marina operators and staff training allows to formulate the following conclusions:

1. Despite the lack of a market product offer, there is a need to organize training courses for marina staff, both in management and operational positions. Due to the intensive development of nautical tourism in the Baltic Sea area, this interest is likely to grow in the coming years.

2. Due to the need for marinas to perform complex activities of a diverse nature, it is necessary to include various thematic blocks in the training program.

3. In the recruitment process, the problem of poor or lack of English skills among marina employees (mainly from Germany) was found. On the one hand, it can be stated that subsequent training should be organized in national languages. On the other hand, this may be a signal that the requirements at the recruitment stage should be tightened, because English skills of employees in direct contact with foreign clients are often necessary.

4. The training program must correspond to the current situation and trends observed in nautical tourism. Confirmation of this is the large interest of participants in issues regarding the services for elderly people.

5. There is a demand for training related to IT infrastructure, accounting and marketing, i.e. management topics. This indicates the need to take strategic actions through conscious planning based on reliably collected data.

\section{Bibliography}

Aczel A.D., Sounderpandian J., 2018, Statystyka w zarzadzaniu, PWN, Warszawa.

Armstrong M., 2001, Zarzqdzanie zasobami ludzkimi - strategia i działanie, Dom Wydawniczy ABC, Kraków.

Armstrong M., 2002, Zarzqdzanie zasobami ludzkimi, Oficyna Ekonomiczna, Kraków.

Butowski L., 2018, Morska turystyka żeglarska. Uwarunkowania i konsekwencje rozwoju, PWN, Warszawa.

Forkiewicz M., 2015, Przeglad modeli operatorskich $w$ morskich portach jachtowych, Logistyka, 2/2015, s. 127.

Hubner S.V., Baum M., 2018, Entrepreneurs' human resources development, Human Resource Development Quarterly, Wiley Periodicals, vol. 29, issue 4, pp. 357-381.

Kenney J., Reid M., 1994, Training Interventions, Institute of Personnel and Development, London.

Kunasz M., 2006a, Narzędzia stosowane w praktyce przedsiębiorstw na poszczególnych etapach procesu szkoleniowego, Organizacja i Kierowanie, nr 1, pp. 99-116.

Kunasz M., 2006b, Ocena efektywności szkolenia w przedsiębiorstwie w świetle wyników badań, Studia i Materiały - Wydział Zarządzania, Uniwersytet Warszawski, nr 1, pp. 29-36.

Łaguna M., 2014, Nowe tendencje w podejściu do szkoleń w organizacji, [in:] A.M. Zawadzka, Psychologia zarzadzania $w$ organizacji, PWN, Warszawa.

Łapko A., 2018, Problems of disabled tourists in nautical tourism, Proceedings $4^{\text {th }}$ EATSA - FRANCE 2018, Challenges of Tourism Development in Asia \& Europe. 
Mazurkiewicz B.K., 2010, Porty jachtowe i mariny. Projektowanie, Fundacja Promocji Przemysłu Okrętowego i Gospodarki Morskiej, Gdańsk.

Pender L., Sharpley R. (eds.), 2008, Zarzqdzanie turystyka, PWE, Warszawa.

Pocztowski A., 2007, Zarzadzanie zasobami ludzkimi, PWE, Warszawa.

Przewłocka J., 2009, CAWI-specyfika, wykorzystanie, perspektywy rozwoju, [in:] A. Haber, M. Szałaj, Ewaluacja wobec wyzwań stojacych przed sektorem finansów publicznych, Warszawa.

Rae L., 1999, Planowanie i projektowanie szkoleń, Dom Wydawniczy ABC, Warszawa.

Sevinc F., Güzel T., 2018, Sustainable yacht tourism practices, Management \& Marketing, p. 72.

Romanowska M., 2011, Zarzqdzanie kapitalem ludzkim, Zeszyty Naukowe Uniwersytetu Szczecińskiego, nr 685, Seria: Finanse, Rynki Kapitałowe, Ubezpieczenia, nr 46, p. 172.

Snell S.A., Morris S.S., Bohlander G.W., 2015, Managing Human Resources, Scarborough, Nelson Education, Canada.

Sumathi N., 2018, Tourism management, international journal of latest technology in engineering, Management \& Applied Science (IJLTEMAS), vol. VII, issue IV, p. 148.

Szczepańska-Woszczyna K., 2009, Metody i techniki TQM, Oficyna Wydawnicza Politechniki Warszawskiej, Warszawa.

Szymańska E., 2009, Oczekiwania rynku turystycznego w zakresie kształcenia kadr, Economy and Management, 1, pp. 135-136.

Tokarz-Kocik A., 2016, Kształcenie kadr dla potrzeb obstugi ruchu turystycznego, Ekonomiczne Problemy Turystyki, 34/2016, s. 379.

Wassertourismus in Deutschland Praxisleitfaden für wassertouristische Unternehmen, Kommunen und Vereine, 2012, Bundesministerium für Wirtschaft und Technologie, Silber Druck oHG, Niestetal. www. marinas.pl (7.08.2019).

www.zmigm.org.pl (7.08.2019). 